\author{
金子 治 舘 和男 花田干代美 田中宗男
}

\title{
The Color of The Skin and its Spectral Reflectance as a Function of Correlated Tristimulus Values
}

\author{
Osamu Kaneko, Kazuo Tate, Chiyomi Hanada and Muneo Tanaka
}

\begin{abstract}
Spectrophotomeric measurements on the colors of japanese women's skins ranging from 19 to 47 years of age were carried out by means of the Hitachi Color Analyzer Model 607 . The color of each subject's skin was measured after the removal of any make-up.

(1) The average colors of the skins (forehead, cheek and lower lip) in Munsell renotation system were 3.5 YR 6.0/3.8, 1.6 YR 6.3/3.9, 7.6 R 5.5/4.3, res pectively.

(2) A principal component analysis was made on the spectral reflectances of the skins; it was found that by the first three principal components, the variances of the spectral reflectances on the colors of the foreheads, the cheeks and the lower lips were explained at $98.1 \%, 97.2 \%, 98.0 \%$, respectively.

(3) From the mean of the spectral refletances of the skins and their first three characteristic vectors, the spectral reflectance curves were reconstituted by the scalar multiples of the characteristic vectors as a function of correlated tristimulus values.

The figure of the reconstituted spectral reflectance curves was compared with the curve obtained by the practical measurement at the same tristimulus values.

They have shown good agreement.

(4) The spectral reflectance curves of the metameric colors on the skins, in which a corresponding tristimulus values are the same but the spectral compositions are different, were reconstituted by the liner combination of the first sixth characteristic vectors and the mean spectral reflectance.
\end{abstract}

\section{1. 緒 言}

皮膚色の測定は，従来から数多く抗こなわれてきた。 その中でも, 顔の各部位についてのデータ採取の報 告 ${ }^{1 \sim 7)}$ は数多くなされ, その結果, 顔の各部位の色とそ の分布範囲は，ほぼ把握でさるをでになっていると考元 られる。しかしながら, 個々の部位の分光反射率に関す る実体把握は，まだ充分に拈こなわれていないようであ る。

一方メイクアップ化粧品の色調設計に際して, 皮膚色

資生堂研究所 横浜市港北区新羽町 1050

Shiseido Laboratories

1050 Nippa-cho, Kohoku-ku, Yokohama-shi 233

Japan.
の分光反射率に関する詳細な情報は, 必要不可欠な情報 であると言える。

$$
\text { そこで, }
$$

(1) 個々の皮膚色の分光反射率を測定すると共に，そ れら分光反射率がどのような構成要素から成立している かを明らかにする。

(2) 皮膚色の分布領域内の任意の点の分光反射率をす みやかに入手できる態勢を確立する。又, 同一の 3 刺激 值を示す皮膚色儿怙いて，分光反射率の異なるケース， 即ち, 条件等色を抢こしているケースについても, 数学 的に合成再現し，その中味を検討する。

といらことを研究課題として, 以下に記すような作業 を拉こない，若干の知見を得たので報告する。 
なお，本報では，皮層色として，額・煩・唇の色を検 討対象としているが，以下一括して「皮膚色」と称する ことにする。

\section{2. データ採取：その実施内容}

今回実施した皮膚色データ採取の, 実施内害を表 1 亿 しめす。

表 1 データ採取：その実施内容の概略

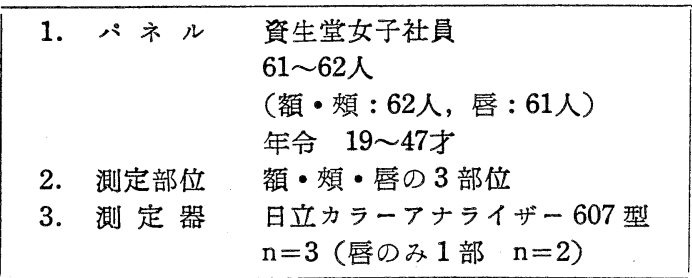

結果として, 380nm〜780nm (10nm 間隔) 41 波長点 の分光反射率データが, 額・類の色について, それぞ れ，186 個，唇の色について $=179$ 個，得られた。

なお，唇（下唇）の色の測定にあたっては，絽 $8 \mathrm{~mm}$ 横 $20 \mathrm{~mm}$ のマスクを積分球開口部にはりつけて測定を 実施した。又, 額・頑・唇の色の, いずれの測定の場合
もメイクアップはすべておとした状態で，分光反射率 を測定している。

\section{3. 結 果}

\section{1 皮虏色の平均値とその分布範围}

得られた分光反射率データをマンセル值に変換して， その平均值を求めてみると, 以下の如くであった。
額の色の平均値
3.5 YR $6.0 / 3.8$
顂の色の平均値
$1.6 \mathrm{YR}$
$6.3 / 3.9$
唇の色の平均值
$\begin{array}{lll}7.6 & \mathrm{R} & 5.5 / 4.3\end{array}$

その分布四を，図1として示す。

\section{2 皮虚色の分光反射率を構成する基本成分の推定}

图 2 に，今回得られた額の色の分光反射率の平均值と パネル (S.A) の額の色の分光反射率をしめす。

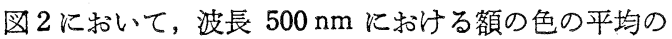
分光反射率と, パネル (S.A) の額の色の分光反射率の 差は, $\Delta \mathrm{R}_{500}=10.2 \%$ である。

ここでは，このような分光反射率差が，どのような構 成要素から成り立っているかを検討する。

図 2 に示した分光反射率差が発生するにあたっていい くつかの構成要素が関与している」と仮定し，一般にこ の分光反射率差を $\Delta \mathrm{R}_{\lambda}$ とすると，(1)式のかたちで書き

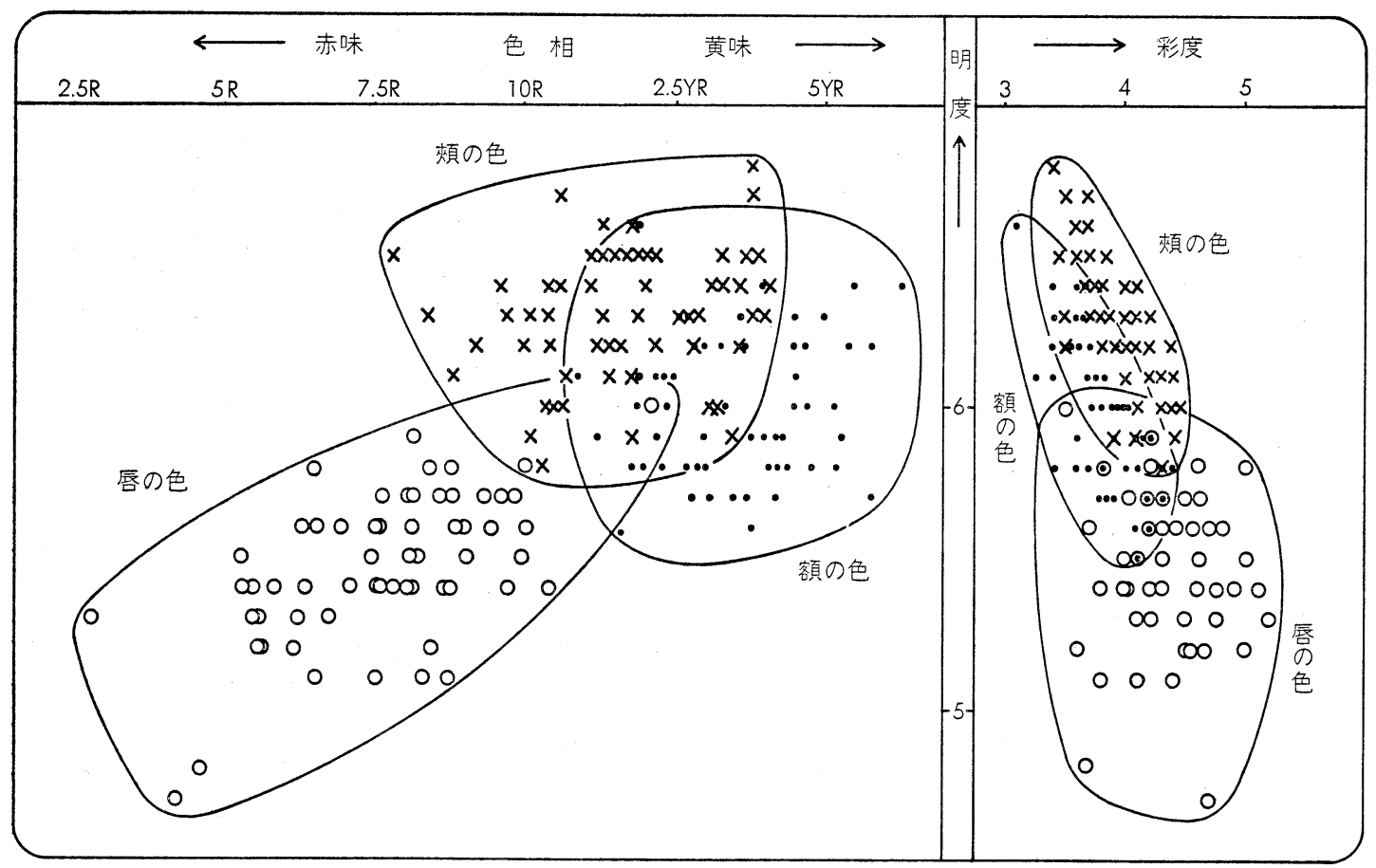

図1今回得られた皮䖉色の分布図（くり返し測定の平均值をプロット） 
皮虐（額・煩・唇）の色とその分光反射率の合成

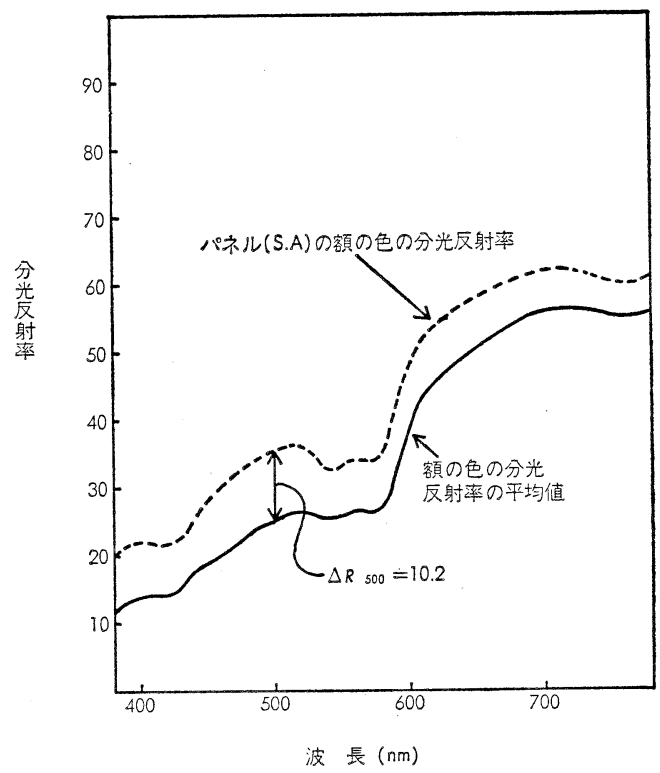

図 2 額の色の分光反射率の平均值とパネル (S.A) の額の色の分光反射射率の実測値 あらわすことができる。

$$
\Delta \mathrm{R}_{\lambda}=f\left(x_{1}, x_{2}, \cdots \cdots x_{\mathrm{n}}\right)
$$

ここで， $x_{1}, x_{2}, \cdots \cdots x_{\mathrm{n}}$ は基本成分（構成要素）を表 わす。

ところで，(1)式で示した関数形の中味は未知である。 ここでは線形構造を仮定しこうした構造を考えた場合 の反射率差 $\Delta \mathrm{R}_{\text {r }}$ を構成する基本成分を推定することに する。

この問題は, 行列の固有值, 固有ベクトルの問題に帰着 する。即ち，主成分分析を行なえばよいことになる。

上記した主旨に従って，今回得られた皮膚色の分光反 射率の，波長間分散・共分散行列の固有方程式を解いて 固有值, 固有ベクトル（本報では, 以下この固有ベクト ルのことことを, 基本成分と称する）を求めた。

この場合， $\Delta \mathrm{R}$. は次のような線形式で表示される。

$$
\Delta \mathrm{R}_{2}=\sum_{i=1}^{n} M_{i} V_{i}
$$

$$
\text { ここで }
$$

$M_{i}$ : 第 基本成分に対寸る重み

$V_{i}, \lambda$ : 波長 $\lambda$ に和ける第 $i$ 基本成分

故に, 各パネルの, 各波長に打ける皮膚色の分光反射 率は, 一般に

$$
R_{\lambda}=\bar{R}_{\lambda}+\Delta \bar{R}_{\lambda}=\bar{R}_{\lambda}+\sum_{i=1}^{n} M_{i} V_{i}, \lambda
$$

ここで

$R_{\lambda}$ : 波長 $\lambda$ に和ける皮膚色の分光反射率

$\bar{R}_{\lambda}$ : 波長 $\lambda$ に和ける皮膚色の分光反射率の平均值 と書さあらわすことができる。

今回採取した皮膚色の分光反射率の，波長間分散・共 分散行列の固有値及び累積寄与率を罯 2 に示す。

表 2 固有值及び累積寄与率

\begin{tabular}{|c|c|c|c|}
\hline & 主成分 & 固 有 值 & 累積寄与率 \\
\hline \multirow{3}{*}{ 額 } & 1 & 268.6 & $87.9 \%$ \\
\cline { 2 - 4 } & 2 & 19.5 & 94.3 \\
\cline { 2 - 4 } & 3 & 11.8 & 98.1 \\
\hline \multirow{3}{*}{ 煩 } & 1 & 217.6 & 82.4 \\
\cline { 2 - 4 } & 2 & 25.5 & 92.1 \\
\hline \multirow{3}{*}{ 唇 } & 3 & 13.5 & 97.2 \\
\hline & 2 & 353.7 & 86.3 \\
\hline & 3 & 33.7 & 94.5 \\
\hline & 2 & 14.2 & 98.0 \\
\hline
\end{tabular}

表 2 か, 皮膚色の分光反射率の変動（個人差）は， $2 \sim 3$ の主成分をとりあげれば，ほぼ説明ができること がわかる。

表 2 に示した個々の 固有值に 対応する 固有ベクトル （前述したように本報に括ける基本成分。なお，第 1 主 成分を求めるための係数を第 1 基本成分。第 2 主成分を 求めるための係数を第 2 基本成分。以下，第 $i$ 主成分を 求めるための係数を第 $i$ 基本成分という）をグラフ化し て図 3 に示す。図 3 には，第 1 基本成分，第 2 基本成分 のみを図示した。

以上のことから，今回対象とした皮膚色の分光反射率 の個人差は，図 3 に示した第 1 ，第 2 (ないしは第 3 ） 基本成分のもらあわせ量（重み $M_{i}$ ）が，個人ごとに異 なることに基づくと考えて，ほ涪問題がないといえる。

いま仮に，第 3 基本成分までをとりあつかい対象とす ると，(3)式は(4)式の如くとなる。

$$
R_{\lambda}=\bar{R}_{\lambda}+M_{1} V_{1, \lambda}+M_{2} V_{2, \lambda}+M_{3} V_{3, \lambda}
$$

$$
\text { ここで }
$$

$M_{1}, M_{2}, M_{3}$ : 第 1 ,第 2 , 第3基本成分に対する重み $V_{1}, \lambda . V_{2}, \lambda . V_{3}, \lambda$ : 波長 $\lambda$ に打壮る第 1 , 第 2 , 第 3 基本成分 


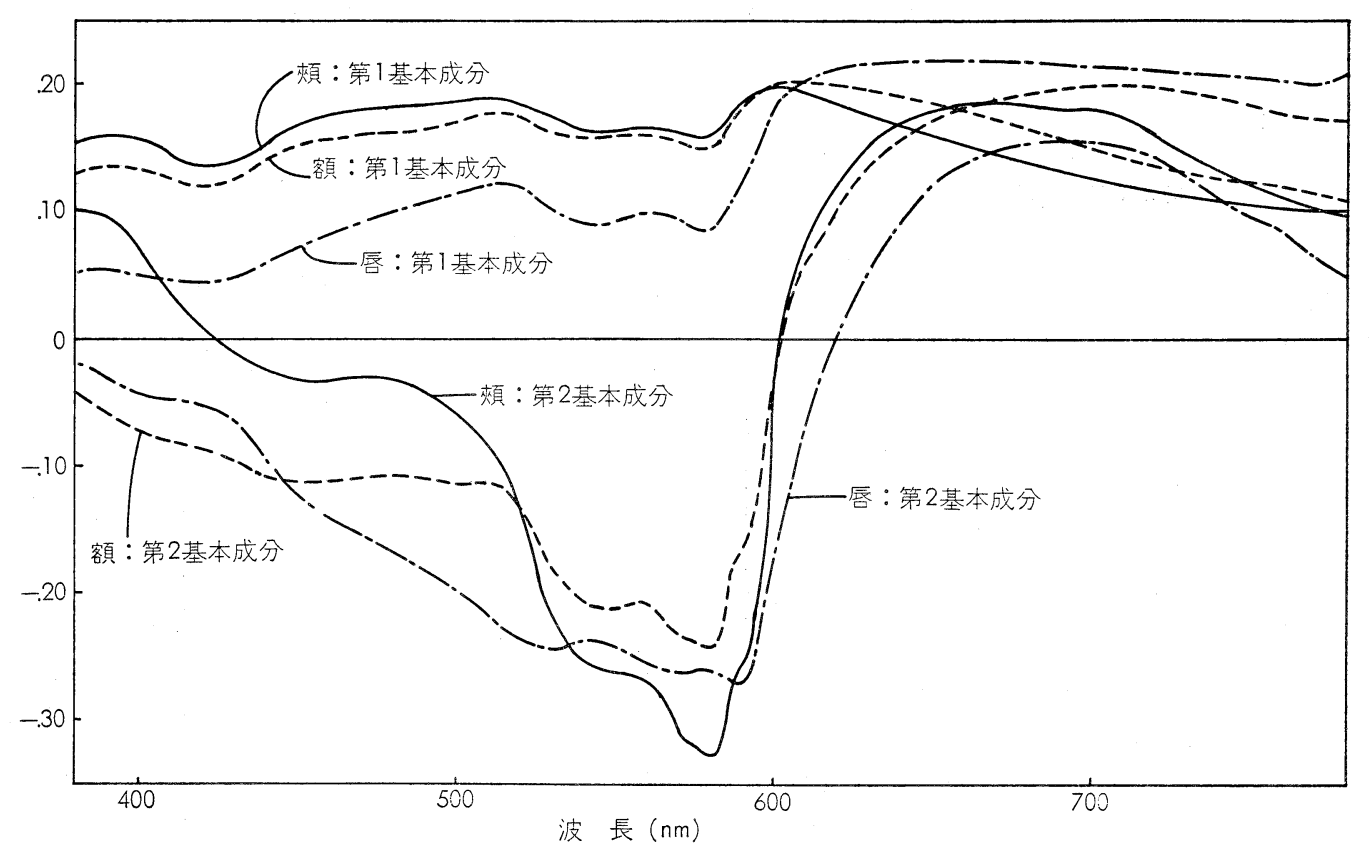

図 3 額, 煩, 唇の 3 部位の色を構成する基本成分

ここで, これら基本成分の発生が何に由来するのかを 考穴てみると, 第 1 基本成分は注注血液の色に起因する と考えるのが妥当であると思われる。

因に，図 3 に示した第 1 基本成分にみられる吸収帯は 酸化へモグロビンによってもたらされる吸収帯 ${ }^{87} ， 417$ $\mathrm{nm}, 548 \mathrm{~nm}, 578 \mathrm{~nm}$ と一致する。

従って, 表 2 からわかるように皮膚色の分光反射率の 変動（個人差）の $82.4 \%$ 87.9\% は, 血液の色の反映 度合いをその源としていると考えることができる。

しかしながら，第 2 , 第 3 基本成分の発生原因は，今 のところ不明である。

\section{3 皮膚色の分光反射率の合成}

緒言でも述べたように，今回の，あるいは従来おこな われてきた皮膚色の測定結果から，皮膚色の分布範囲は 把握できるわけだが，その分布領域の任意の 1 点の分光 反射率は，偶然にその 1 点にかさなる測定例がなければ 知ることはできない。

ここでは, 皮膚色の分布領域内の任意の点の分光反射 率がすみやかに入手できる態勢づくりの確立をはかる。

表 2 亿示したように, 皮膚色の分光反射率の変動は, 第 1 ，第 2 ，第 3 主成分をとりあげることによって 97.2 \% 98.1\%, 説明できる。この説明量は非常に大きいと 考えられるので, これら 3 ッの主成分を用いて, 皮膚色
の分光反射率を合成することを考えた。な就，3つの主 成分をとりあげたもう 1つの理由として，後記する(8)式 即ち 3 元 1 次連立方程式を解くことによって必要な值を 求めよらとしたことがあげられる。

分光分布の合成関する報告としては，ともに任意の 色度点と分光分布とを対応させた，CIE 合成昼光に関す る Judd 等の報告9)，けい光灯の分光分布の合成に関する 納谷等の報告 ${ }^{10)}$ がある。

ここでは, 皮膚色の分布領域内の任意の 1 点をしめす 3 刺激值 $X, Y, Z$ と, 皮膚色の分光反射率の結びつけ を考光，当該皮膚色の分光反射率を合成する。

な技，本報に打いて対象としている皮膚色の中で，居

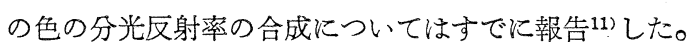
他の皮膚色，即ち額の色，㛲の色の分光反射率の合成も まったく同じ手順をとったので，以下合成過程を再録す る。皮膚色の 3 刺激值 $X, Y, Z$ は，(5)式のかたちで書 きあらわされる。

$$
\left.\begin{array}{ll}
X=\sum & E_{\lambda} R_{\lambda} \bar{x}_{\lambda} d_{\lambda} \\
Y=\sum & E_{\lambda} R_{\lambda} \bar{y}_{\lambda} d_{\lambda} \\
Z=\sum & E_{\lambda} R_{\lambda} \bar{z}_{\lambda} d_{\lambda}
\end{array}\right\} .
$$

なお。,(5)式に括ける $E_{\lambda}$ は C 光源を, $\bar{x}_{\lambda}, \bar{y} \lambda, \bar{z}_{\lambda}$ は1931 年 $\mathrm{CIE}$ 標準観測者のスペクトル 3 刺激值を意味する。 
(4)式を(5)式に代入すると，(6)式が得られる。

$$
\left.\begin{array}{l}
X=\sum\left(\overline{\boldsymbol{R}}_{\lambda}+M_{1} V_{1}, \lambda+M_{\mathbf{2}} V_{\mathbf{2}}, \lambda+M_{3} V_{3}, \lambda\right) E_{\lambda} \bar{x}_{\lambda} d_{\lambda} \\
Y=\sum\left(\overline{\boldsymbol{R}}_{\lambda}+M_{1} V_{1}, \lambda+M_{2} V_{\mathbf{2}}, \lambda+M_{3} V_{3}, \lambda\right) E_{\lambda} \bar{y}_{\lambda} d_{\lambda} \\
Z=\sum\left(\overline{\boldsymbol{R}}_{\lambda}+M_{1} V_{1}, \lambda+M_{\mathbf{2}} V_{\mathbf{2}}, \lambda+M_{3} V_{3}, \lambda\right) E_{\lambda} \bar{z}_{\lambda} d_{\lambda}
\end{array}\right\} \cdots(6)
$$

(6)式は，(7)式のかたちに書きかえることができる。

$$
\left.\begin{array}{l}
X=X_{0}+M_{1} X_{1}+M_{2} X_{2}+M_{3} X_{3} \\
Y=Y_{0}+M_{1} Y_{1}+M_{2} Y_{2}+M_{3} Y_{3} \\
Z=Z_{0}+M_{1} Y_{1}+M_{2} Y_{2}+M_{3} Z_{3}
\end{array}\right\}
$$

ここで， $X_{0} ， Y_{0}, Z_{0}$ は皮膚色の分光反射率の平均值 によってもたらされる 3 刺激值であり， $X_{1}, Y_{1}, Z_{1}$, $X_{2}, Y_{2}, Z_{2}, X_{3}, Y_{3}, Z_{3}$ は，第 1 ，第 2 ，第 3 基本成
分によってもたらされる 3 刺激值である。

例㝋ば, $X_{1}=\sum V_{1},{ }_{\lambda} E_{\lambda} \bar{x}_{\lambda} d_{\lambda} \quad Y_{1}=\sum V_{1},{ }_{\lambda} E_{\lambda} \bar{y}_{\lambda} d_{\lambda}$ $Z_{1}=\sum V_{1},{ }_{\lambda} E_{\lambda} \bar{z}_{\lambda} d_{\lambda}$ である。

$X^{\prime}=\left(X-X_{0}\right), Y^{\prime}=\left(Y-Y_{0}\right), Z^{\prime}=\left(z-z_{0}\right)$ とおいて, (7)式を書きかえて，(8)式とする。

$$
\begin{aligned}
& X^{\prime}=M_{1} X_{1}+M_{2} X_{2}+M_{3} X_{3} \\
& Y^{\prime}=M_{1} Y_{1}+M_{2} Y_{2}+M_{3} Y_{3} \\
& Z^{\prime}=M_{1} Z_{1}+M_{2} Z_{2}+M_{3} Z_{3}
\end{aligned}
$$

(8)式において, 未知数は $M_{1}, M_{2}, M_{3}$ のみである。 そこで, $M_{1}, M_{2}, M_{3}$ について, (8) 式を解くと, (9) 式 が得られる。

$$
\left.\begin{array}{c}
M_{1}=\frac{X^{\prime} Y_{2} Z_{3}+Y^{\prime} Z_{2} X_{3}+Z^{\prime} X_{2} Y_{3}-X^{\prime} Z_{2} Y_{3}-Y^{\prime} X_{2} Z_{3}-Z^{\prime} Y_{2} X_{3}}{X_{1} Y_{2} Z_{3}+Y_{1} Z_{2} X_{3}+Z_{1} X_{2} Y_{3}-X_{1} Z_{2} Y_{3}-Y_{1} X_{2} Z_{3}-Z_{1} Y_{2} X_{3}} \\
M_{2}=\frac{Y^{\prime} X_{1} Z_{3}+Z^{\prime} Y_{1} X_{3}+X^{\prime} Z_{1} Y_{3}-Z^{\prime} X_{1} Y_{3}-X^{\prime} Y_{1} Z_{3}-Y^{\prime} Z_{1} X_{3}}{X_{1} Y_{2} Z_{3}+Y_{1} Z_{2} X_{3}+Z_{1} X_{2} Y_{3}-X_{1} Z_{2} Y_{3}-Y_{1} X_{2} Z_{3}-Z_{1} Y_{2} X_{3}} \\
M_{3}=\frac{Z^{\prime} X_{1} Y_{2}+X^{\prime} Y_{1} Z_{2}+Y^{\prime} Z_{1} X_{2}-Y^{\prime} X_{1} Z_{2}-Z^{\prime} Y_{1} X_{2}-X^{\prime} Z_{1} Y_{2}}{X_{1} Y_{2} Z_{3}+Y_{1} Z_{2} X_{3}+Z_{1} X_{2} Y_{3}-X_{1} Z_{2} Y_{3}-Y_{1} X_{2} Z_{3}-Z_{1} Y_{2} X_{3}}
\end{array}\right)
$$

今回得られた皮膚色の 分光反射率の平均値，並びに第 1 ，第 2 ，第 3 基本成分を表 3 ，表 4 ，表 5 に示す。

表 3 額の色の分光反射率の平均值並びに第 1 , 第 2 ，第 3 基本成分

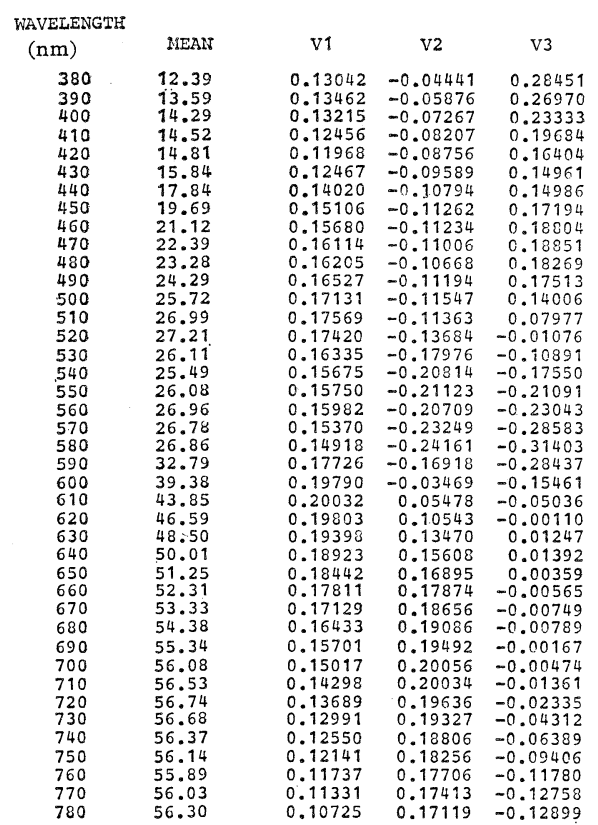

表 4 煩の色の分光反射率の平均值並びに第 1 , 第 2 , 第 3 基本成分

\begin{tabular}{ccccc} 
WAVELENGTH & \multicolumn{4}{c}{ V } \\
(nm) & MEAN & v1 & $\mathrm{v} 2$ & $\mathrm{~V} 3$ \\
380 & 14.62 & 0.15405 & -0.11712 & -0.32301 \\
390 & 16.20 & 0.15916 & -0.09730 & -0.30386 \\
400 & 17.23 & 0.15475 & -0.06784 & -0.27205 \\
410 & 17.70 & 0.14335 & -0.03416 & -0.23025 \\
420 & 18.15 & 0.13578 & -0.00923 & -0.19369 \\
430 & 19.35 & 0.13933 & 0.00639 & -0.18010 \\
440 & 21.54 & 0.15476 & 0.02564 & -0.17933 \\
450 & 23.44 & 0.16769 & 0.03047 & -0.16187 \\
460 & 24.91 & 0.17509 & 0.03060 & -0.14953 \\
470 & 26.26 & 0.18029 & 0.02939 & -0.13669 \\
480 & 27.23 & 0.18232 & 0.03235 & -0.12767 \\
490 & 28.23 & 0.18329 & 0.03923 & -0.11048 \\
500 & 29.62 & 0.18488 & 0.05910 & -0.08324 \\
510 & 30.82 & 0.18778 & 0.08449 & -0.05200 \\
520 & 30.74 & 0.18416 & 0.13782 & 0.00032 \\
530 & 29.14 & 0.17285 & 0.21008 & 0.05263 \\
540 & 28.28 & 0.16397 & 0.25207 & 0.08415 \\
550 & 28.94 & 0.16420 & 0.26059 & 0.09295 \\
560 & 29.94 & 0.16562 & 0.26720 & 0.11245 \\
570 & 29.34 & 0.16058 & 0.30872 & 0.14358 \\
580 & 29.21 & 0.15813 & 0.32662 & 0.16921 \\
590 & 36.23 & 0.18626 & 0.25738 & 0.17438 \\
600 & 44.97 & 0.19690 & 0.06884 & 0.07203 \\
610 & 50.39 & 0.19243 & -0.06513 & 0.02559 \\
620 & 53.33 & 0.18429 & -0.12717 & 0.01007 \\
630 & 55.22 & 0.17602 & -0.15214 & 0.01420 \\
640 & 56.65 & 0.16721 & -0.17228 & 0.02279 \\
650 & 57.77 & 0.16006 & -0.17948 & 0.03755 \\
660 & 58.72 & 0.15243 & -0.18216 & 0.05083 \\
670 & 59.54 & 0.14620 & -0.18235 & 0.07226 \\
680 & 60.34 & 0.14035 & -0.18468 & 0.09154 \\
690 & 61.04 & 0.13206 & -0.17961 & 0.10621 \\
700 & 61.56 & 0.12801 & -0.17999 & 0.12554 \\
710 & 61.82 & 0.12210 & -0.17289 & 0.14385 \\
720 & 61.85 & 0.11669 & -0.16035 & 0.15831 \\
730 & 61.63 & 0.11239 & -0.14952 & 0.17390 \\
740 & 61.26 & 0.10644 & -0.13501 & 0.18757 \\
750 & 61.01 & 0.10430 & -0.12392 & 0.20257 \\
760 & 60.72 & 0.10244 & -0.11509 & 0.21333 \\
770 & 60.87 & 0.10099 & -0.10323 & 0.22749 \\
780 & 61.06 & 0.09972 & -0.09503 & 0.23913
\end{tabular}


表 5 唇の色の分光反射率の平均值並びに第 1 ， 第 2 , 第 3 基本成分

\begin{tabular}{|c|c|c|c|c|}
\hline $\begin{array}{c}\text { WAVELENGTH } \\
\text { (nm) }\end{array}$ & MEAN & v? & v2 & v3 \\
\hline $\begin{array}{l}380 \\
390 \\
400 \\
410 \\
420 \\
430 \\
440 \\
450 \\
460 \\
470 \\
480 \\
490 \\
500 \\
510 \\
520 \\
530 \\
540 \\
550 \\
560 \\
570 \\
580 \\
590 \\
600 \\
610 \\
620 \\
630 \\
640 \\
650 \\
660 \\
670 \\
680 \\
690 \\
700 \\
710 \\
720 \\
730 \\
740 \\
750 \\
760 \\
770 \\
780\end{array}$ & $\begin{array}{l}15.22 \\
15.46 \\
15.39 \\
15.22 \\
15.16 \\
75.62 \\
16.60 \\
77.67 \\
78.52 \\
79.32 \\
19.81 \\
20.17 \\
21.01 \\
21.68 \\
21.40 \\
19.99 \\
19.25 \\
19.82 \\
20.83 \\
20.30 \\
19.88 \\
24.63 \\
32.64 \\
39.10 \\
42.89 \\
45.73 \\
47.88 \\
49.57 \\
50.85 \\
51.93 \\
52.99 \\
53.97 \\
54.63 \\
54.88 \\
54.83 \\
54.58 \\
54.12 \\
53.74 \\
53.14 \\
52.78 \\
53.10\end{array}$ & $\begin{array}{l}0.05447 \\
0.05381 \\
0.05010 \\
0.04620 \\
0.04526 \\
0.04845 \\
0.05977 \\
0.07129 \\
0.08194 \\
0.09070 \\
0.10004 \\
0.10647 \\
0.11430 \\
0.12196 \\
0.11890 \\
0.10104 \\
0.08911 \\
0.09134 \\
0.09861 \\
0.09281 \\
0.08357 \\
0.12774 \\
0.17710 \\
0.20214 \\
0.21129 \\
0.21485 \\
0.21696 \\
0.21569 \\
0.21566 \\
0.21713 \\
0.21717 \\
0.21549 \\
0.21449 \\
0.21232 \\
0.20950 \\
0.20675 \\
0.20613 \\
0.20486 \\
0.20083 \\
0.20088 \\
0.20787\end{array}$ & $\begin{array}{l}-0.01766 \\
-0.03041 \\
-0.04266 \\
-0.04764 \\
-0.05220 \\
-0.06418 \\
-0.09419 \\
-0.12102 \\
-0.14176 \\
-0.15472 \\
-0.16828 \\
-0.18208 \\
-0.19955 \\
-0.21649 \\
-0.23740 \\
-0.24369 \\
-0.23618 \\
-0.24146 \\
-0.25402 \\
-0.26249 \\
-0.25954 \\
-0.26992 \\
-0.18328 \\
-0.07576 \\
-0.00114 \\
0.05475 \\
0.09242 \\
0.11958 \\
0.13706 \\
0.14888 \\
0.15190 \\
0.15620 \\
0.15360 \\
0.15135 \\
0.13492 \\
0.12625 \\
0.10993 \\
0.09352 \\
0.08386 \\
0.06539 \\
0.04767\end{array}$ & $\begin{array}{r}-0.20379 \\
-0.16456 \\
-0.12606 \\
-0.09142 \\
-0.07214 \\
-0.06949 \\
-0.08234 \\
-0.10156 \\
-0.11131 \\
-0.12050 \\
-0.11984 \\
-0.11430 \\
-0.10223 \\
-0.07899 \\
-0.02486 \\
0.04173 \\
0.08047 \\
0.09823 \\
0.10075 \\
0.12536 \\
0.18438 \\
0.12972 \\
-0.00184 \\
-0.12056 \\
-0.18973 \\
-0.21815 \\
-0.22003 \\
-0.20345 \\
-0.18316 \\
-0.14203 \\
-0.09206 \\
-0.05512 \\
-0.00901 \\
0.03973 \\
0.09386 \\
0.14138 \\
0.20404 \\
0.25266 \\
0.29543 \\
0.32838 \\
0.36001\end{array}$ \\
\hline
\end{tabular}

個々の皮唐色について，それぞれ別個に， $X_{0} ， Y_{0}$, $Z_{0}, X_{1}, Y_{1}, Z_{1}, X_{2}, Y_{2}, Z_{2}, X_{3}, Y_{3}, Z_{3}$ を求め て(9)式に代入すると, (10), (11), (12) 式が得られる。 なお，(10)，(11)，(12）に扣ける 3 刺激值 $X, Y, Z$ は, \%表示である。

すでに知られている皮膚色の分布領域内の 1 点をしめ す 3 刺激值 $X, Y, Z$ から, 当該部位の分光反射率を合 成するには

(1) 当該部位の 3 刺激値 $X, Y, Z$ を 額の場合には, (10)式に) 煩の場合には，(11)式に\}それぞれ代入する。 唇の場合には,(12)式に)

(2) 得られた $M_{1}, M_{2}, M_{3}$ を（4)式に代入する。 以上の手順を踏むことによって, 当該部位の分光反射 率を合成することがでさる。

なお，実用に除しては，IBM call システムを利用し ている。

上記した方法に従って，個々の皮庴色の分光反射率の 合成を試みたが，唇の色については前述したようにすで に報告したのでここでは, 額, 顂の色の分光反射率の合 成例を図 4, 図 5 に示す。

額の色の分光反射率に関する $M_{1}, M_{2}, M_{3}$ を求める式。

$$
\left.\begin{array}{l}
M_{1}=\frac{-0.043712 X+0.025274 Y-0.002530 Z+0.722444}{-0.003515} \\
M_{2}=\frac{-0.055502 X+0.047881 Y+0.007113 Z+0.200314}{-0.003515} \\
M_{3}=\frac{0.003117 X+0.008433 Y-0.011032 Z+0.094226}{-0.003515}
\end{array}\right\}
$$

頓の色の分光反射率に関する $M_{1}, M_{2}, M_{3}$ を求める式。

$$
\left.\begin{array}{l}
M_{1}=\frac{-0.032566 X+0.016339 Y-0.000679 Z+0.668126}{-0.002803} \\
M_{2}=\frac{0.043887 X-0.037677 Y-0.004526 Z-0.221150}{-0.002803} \\
M_{3}=\frac{-0.027257 X+0.010918 Y-0.013883 Z+0.247803}{-0.002803}
\end{array}\right\}
$$

辰の色の分光反射率に関する $M_{1}, M_{2}, M_{3}$ を求める式。

$$
\begin{aligned}
& M_{1}=\frac{0.027158 X-0.012221 \mathrm{Y}-0.007972 Z-0.292640}{0.001420} \\
& M_{2}=\frac{0.015937 X-0.013166 Y-0.006057 Z-0.002568}{0.001420} \\
& M_{3}=\frac{0.000719 X+0.007298 Y-0.010841 Z+0.031944}{0.001420}
\end{aligned}
$$


皮膚（額・煩・唇）の色と乞の分光反射率の合成

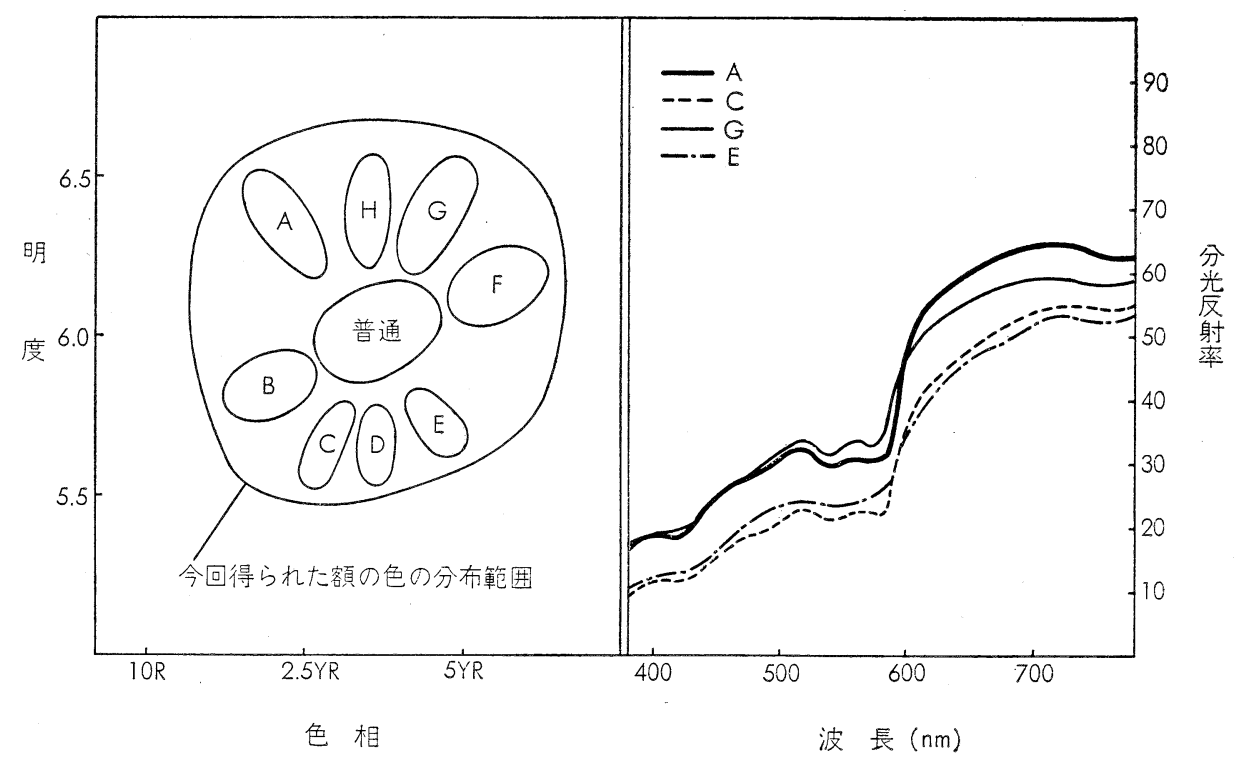

図4 分光反射率の系統的な相違に基づく額の色の分類結果（左罒）と当該分類 領域の額の色の分光反射率の合成例（右図）を示す。

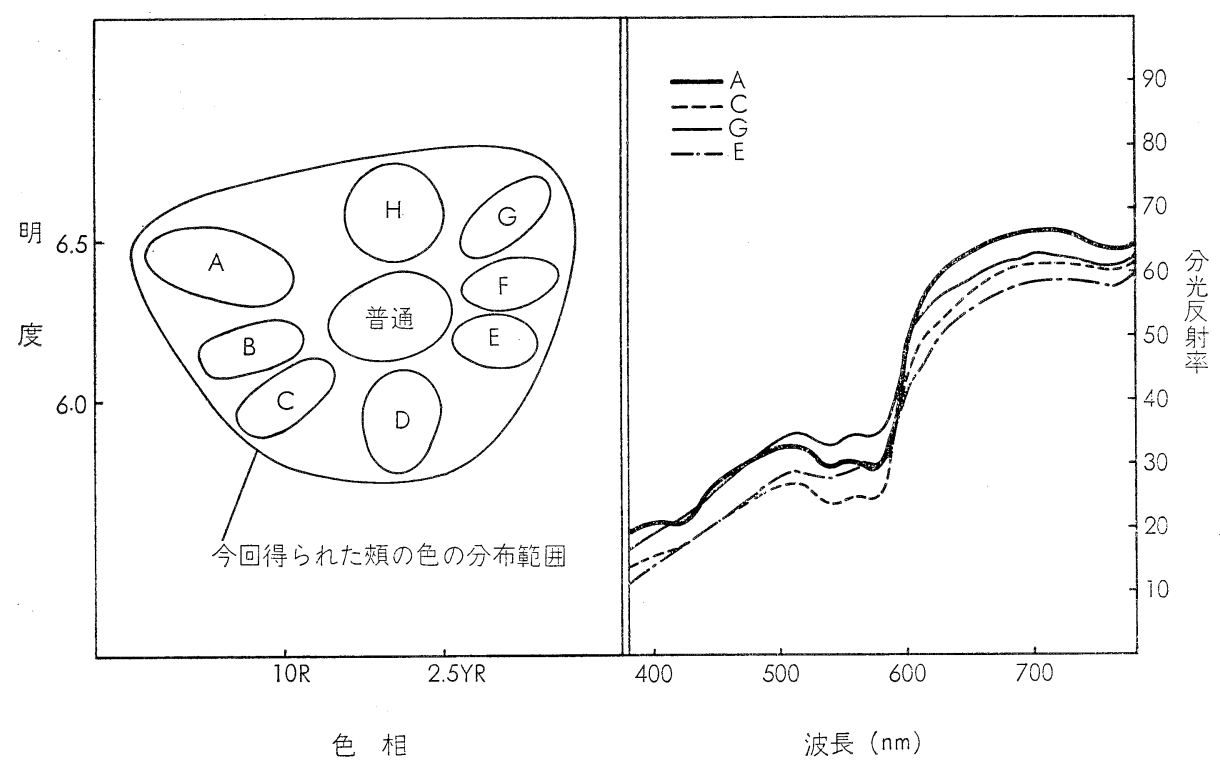

図 5 分光反射率の系統的な相違に基づく煩の色の分類結果（左図）と当該分類 領域の煩の色の分光反射率の合成例（右図）を示す。

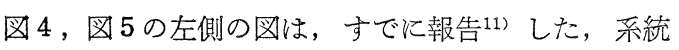
的な分光反射率の相違に基づく皮膚色の分類といら方法 によって，9つに分類した皮膚色の分類領域を大雑把に

\section{示したものである。}

ただし，それぞれの分類領域は，今回得られた皮庿色 の分布範围内に怙さまるように，中心方向に圧縮されて 
いる。

又, 圧縮の度合いも一率ではない。

右側の図は, 左図 A， C , E， G の領域核当する皮 膚色の合成分光反射率をグラフ化したものである。

以上のようにして代表的な皮層色とその合成分光反射 率が得られた。

なお，本報に拈いては額，煩，唇の色の分光反射率を それぞれ別個の式を用いて合成しているが，1つにをと めることも当然可能である。

\section{4 条件等色をおこしている 皮膚色の 分光反射率の} 合成

表 2 からわかるように，第 1 , 第 2 , 第 3 主成分に上 って説明される分光反射率の変動は, 額・顂・唇の色に 関して，それぞれ，98.1\%，97.2\%，98.0\%と非常に高 い。従って合成した分光反射率の再現性は, 非常に高い と予測される。事実, 実測することによって得られた皮 膚色の 3 刺激值 $X, Y, Z$ を用いて当該部位の合成分光 反射率を求め, 実測した分光反射率と対応させると, き わめて良好な一致をしめしていた。1 例を図6亿示す。

しかしながら，上記した数字からわかるように， 1.9
$\%, 2.3 \%, 2.0 \%$ とい5分光反射率の 変動は未説明量 として残されている。

事実, 個々のパネルについて基本成分のもちあわせ量 $\left(M_{i}\right)$ を調べてみると，第 4 基本成分以下の基本成分の もち合せ量が比較的大きいパネルの存在が散見される。 従って大部分の皮膚色の分光反射率は, 第 1 , 第 2 , 第 3 基本成分から構成されているといえるが, 中には, 第 4 基本成分以下の基本成分が, 分光反射率の構成要素々

して働いている皮層色が存在していることになる。 このことは, 3 刺激值 $X, Y, Z$ は同じだが, 分光反 射率の異なる皮管色が存在することを意味している。

ここでは上記した未説明量として残されている変動部 分もとりあげることによって，同じ 3 刺激值をもちなが ら分光反射率が異なるといら皮膚色の実体を明らかにす る。表 6 江第 4 主成分以下の固有值, 寄与率をしめす。 表 6 からわかるように，第 7 主成分の寄与率は $0.1 \%$ と小さい。そこでこれを無視するとして，ここでは第 4 , 第 5 , 第 6 主成分を検討対象とする。

第 4 , 第 5 , 第 6 主成分を求めるための保数, 即ち, 第 4 , 第 5 , 第 6 基本成分が関与することによって, 分

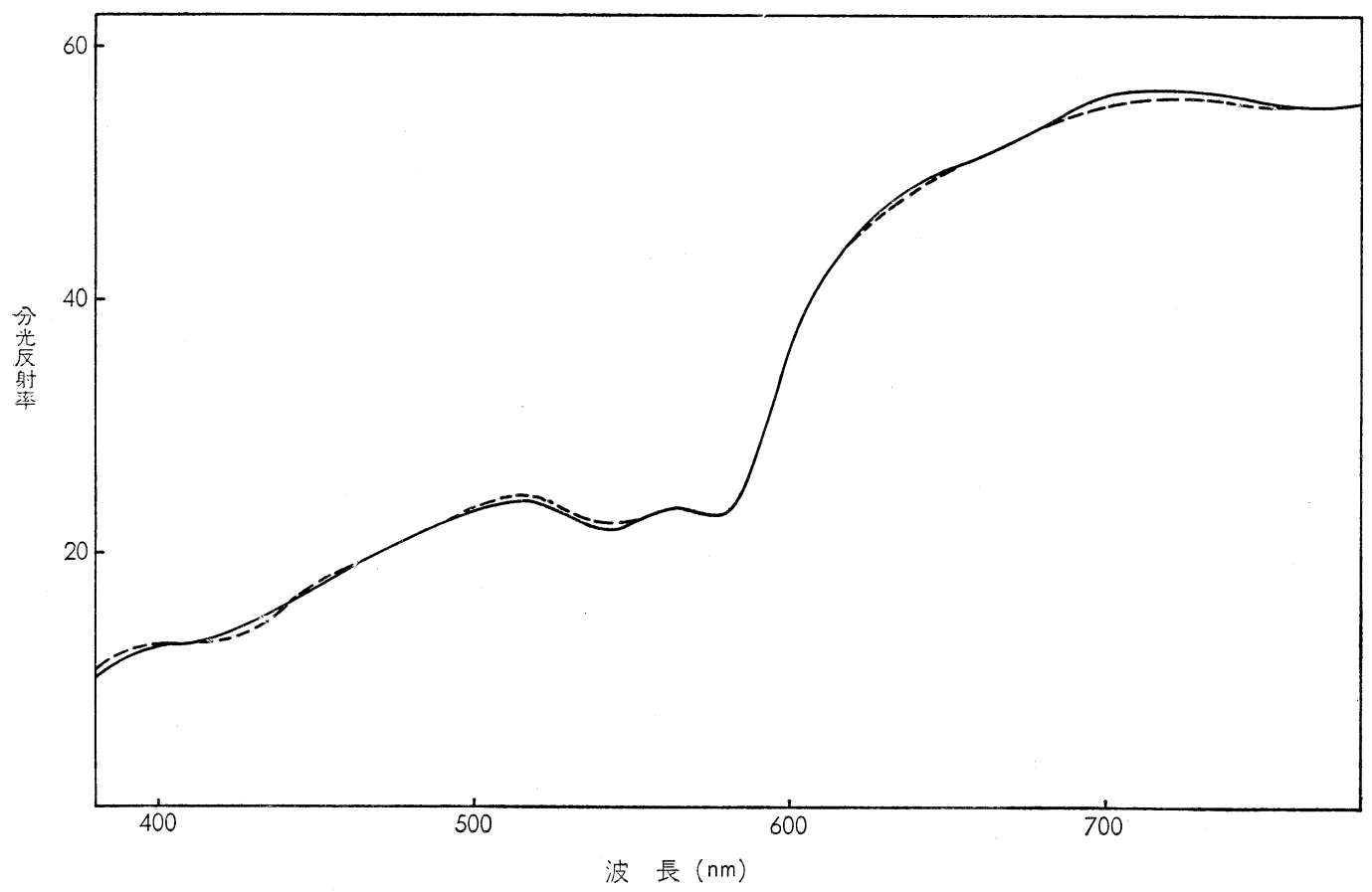

図 6 パネル (C.H) の額の色の分光反射率曲線。実線は実測值, 点線は合成值。 
表 6 固有値及び寄与率。（）内は累積奇与率。

\begin{tabular}{|c|c|c|c|}
\hline & 主成分 & 固 有 值 & 寄 与 率 \\
\hline \multirow{4}{*}{ 額 } & 4 & 2.2 & $0.7(98.8)$ \\
\hline & 5 & 2.1 & $0.7(99.5)$ \\
\hline & 6 & 0.5 & $0.2(99.7)$ \\
\hline & 7 & 0.2 & $0.1(99.8)$ \\
\hline \multirow{4}{*}{ 顃 } & 4 & 3.2 & $1.2(98.4)$ \\
\hline & 5 & 2.1 & $0.8(99.2)$ \\
\hline & 6 & 0.7 & $0.3(99.5)$ \\
\hline & 7 & 0.4 & $0.1(99.6)$ \\
\hline \multirow{4}{*}{ 唇 } & 4 & 3.4 & $0.8(98.8)$ \\
\hline & 5 & 2.2 & $0.6(99.4)$ \\
\hline & 6 & 0.8 & $0.2(99.6)$ \\
\hline & 7 & 0.5 & $0.1(99.7)$ \\
\hline
\end{tabular}

光反射率がどうかわるかは，第 4 ，第 5 ，第 6 基本成分 のもちあわせ量, $M_{4}, M_{5}, M_{6}$ によって構成される 3 次 元空間の任意の 1 点の分光反射率が同定できれば明らか にされる。勿論, $M_{4}, M_{5}, M_{6}$ の值を設定することでき まる $M_{1}, M_{2}, M_{3}$ の值も関与するわけで, 正確には 6 次元空間の 1 点となるわけだが，ここではこのようなか たちで記述をすすめる。

このことは当然ながら, 条件等色している無限個の分 光反射率データが得られることを意味している。

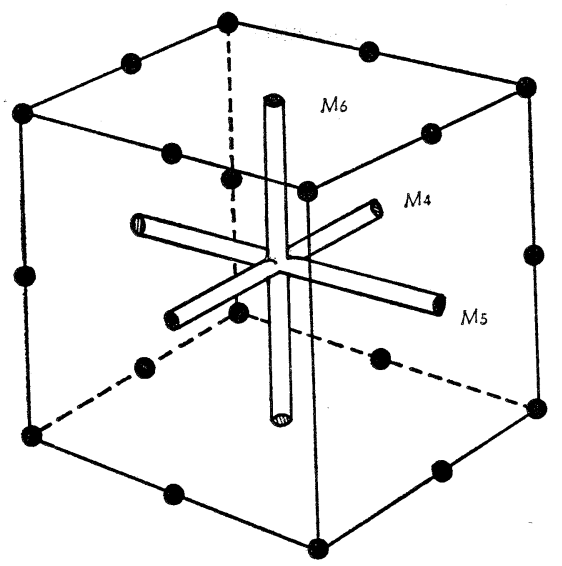

図7 $M_{4}, M_{5}, M_{6}$ によって構成される 3 次元空間之 今回合成した条件等色している分光反射率デー タの位置（の畉）を示す。
$M_{4}, M_{5}, M_{6}$ によって構成される 3 次元空間は, 3 変 量正規分布に従う楕円体となるわけだが，ここでは便宜 的に, 図7に示すよ 5 に, $M_{4}, M_{5}, M_{6}$ の变動の大きさ を, 縦, 横, 高さとした直方体として表示する。

$M_{4}, M_{5}, M_{6}$ の変動の大きさは, 表 6 の固有値から求 めることができる。即ち，第 4 ，第 5 ，第 6 主成分の固 有值の平方根は，それぞれ $M_{4}, M_{5}, M_{6}$ の変動の標準 偏差をあらわしている。但し, 函 7 の $M_{4}, M_{5}, M_{6}$ の 長さは実際の $M_{4}, M_{5}, M_{6}$ の大ささと比例させてない。

ここでは，これも便宜的に $\pm 2 \sigma$ の值をもって， $M_{4}, M_{5}, M_{6}$ の変動の大きさとする。

前述したように，同じ 3 刺激值 $X, Y, Z$ をとる皮膚 色の分光反射率データは無限個存在するわけだが，その 代表例として $M_{4}, M_{5}, M_{6}$ が，それぞれ正負の最大值 をとる 26 ケースに, $M_{4}, M_{5}, M_{6}$ が共に零をとるケー スを加え 27 計ケースの分光反射率を合成し，検討を加 えることにする。

$M_{4}, M_{5}, M_{6}$ が任意の值をとるとき, $M_{1}, M_{2}, M_{3}$ がどのような值をとるかということは, 次の方法で求め た。

ここでは，第 4 , 第 5 ，第 6 基本成分も対象としてい るので，(4)式をかきかえて，(13)式とする。

$$
\begin{aligned}
R_{\lambda}=\bar{R}_{\lambda} & +M_{1} V_{1, \lambda}+M_{2} V_{2, \lambda}+M_{3} V_{3, \lambda} \\
& +M_{4} V_{4, \lambda}+M_{5} V_{5, \lambda}+M_{6} V_{6}, \lambda
\end{aligned}
$$

(5)式に，(13)式を代入し，(7)式にならって書きかえると (14)式の如くになる。

$$
\left.\begin{array}{l}
X=X_{0}+M_{1} X_{1}+M_{2} X_{2}+M_{3} X_{3}+M_{4} X_{4}+M_{5} X_{5}+M_{6} X_{6} \\
Y=Y_{0}+M_{1} Y_{1}+M_{2} Y_{2}+M_{3} Y_{3}+M_{4} Y_{4}+M_{5} Y_{5}+M_{6} Y_{6} \\
Z=Z_{0}+M_{1} Z_{1}+M_{2} Z_{2}+M_{3} Z_{3}+M_{4} Z_{4}+M_{5} Z_{5}+M_{6} Z_{6}
\end{array}\right\}
$$

(14)

次に

$$
\left.\begin{array}{l}
X^{\prime}=\left(X-X_{0}-M_{4} X_{4}-M_{5} X_{5}-M_{6} X_{6}\right) \\
Y^{\prime}=\left(Y-Y_{0}-M_{4} Y_{4}-M_{5} Y_{5}-M_{6} Y_{6}\right) \\
Z^{\prime}=\left(Z-Z_{0}-M_{4} Z_{4}-M_{5} Z_{5}-M_{6} Z_{8}\right)
\end{array}\right\} \text { とおいて }
$$

(14) 式を書きかえ，(8)式のかたちにする。このあと， $M_{1}, M_{2}, M_{3}$ を末知数として (9) 式をうるのは, 前記し たとおりである。

従って, 3 刺激值 $X, Y, Z$ と $M_{4}, M_{5}, M_{6}$ の值を 設定すれば， $M_{1} ， M_{2}, M_{3}$ がもとまり，これらを(13)式 
に代入することで条件等色している皮膚色の分光反射率 を合成することができる。

上記した手続きで，条件等色している分光反射率デー タ27ケースを各部位の皮虔色について合成した。

用いた 3 刺激值 $X, Y, Z$ は, 今回得られた額・頓・ 唇の色の分光反射率の平均值から求めた 3 刺激值 $X$, $Y, Z$ である。これを表 7 にしす。

表 7 条件等色している $27 ケ ー ス の$ 分光反射率データ を求める際に用いた 3 部位の 3 刺激值（\%表 示)

\begin{tabular}{|c|c|c|c|}
\hline & $X$ & $Y$ & $Z$ \\
\hline 額 & 32.50 & 29.99 & 23.57 \\
\hline 煩 & 36.82 & 33.66 & 27.97 \\
\hline 唇 & 27.87 & 24.22 & 21.10 \\
\hline
\end{tabular}

得られた額の色に関する合成分光反射率のデータ例を 図 8 に示す。

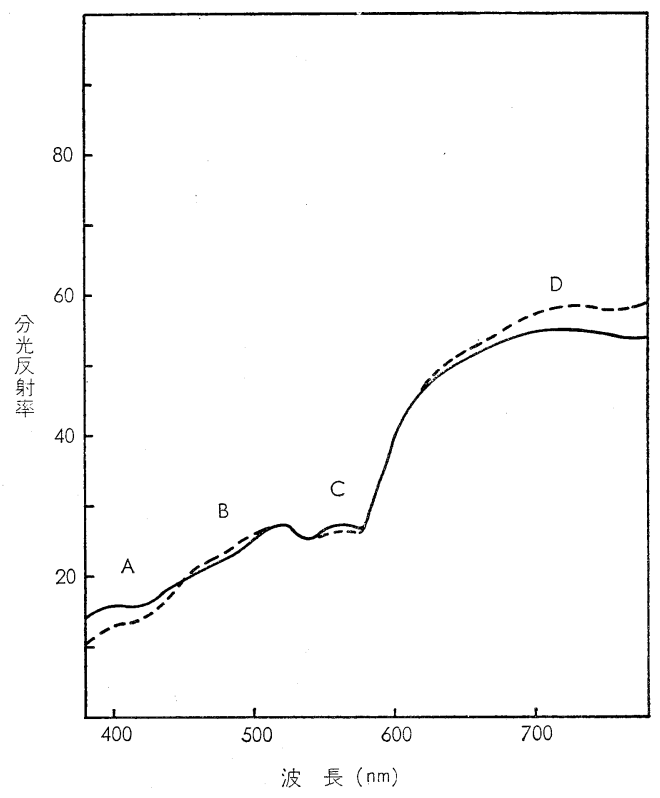

図 8 条件等色としている額の色の分光反射率の 合成例

図 8 に示した分光反射率の各波長点に拈けるふれ幅を みると，その大きさに違いがみられる。ここではこの点 に着目して条件等色の発生原因を検討する。
合成した 27 ケースの分光反射率の 各波長点における 最大值, 最小值をぬさだしグラフ化すると, 四8 に酷似 した図が得られる。そこで新しく插罒することなしに図 8 で代用する。

まず図 8 において，反射率のふれ幅の大きい波長領域 を短波長側から A，B，C，D と名づけておく。次に， 各波長点の分光反射率の関連性をみるために, $380 \mathrm{~nm}$ $780 \mathrm{~nm}$ (20nm 間隔) 間の 21 波長点に $550 \mathrm{~nm}$ (酸化一 モグロビン $548 \mathrm{~nm}$ の吸収帯に近いので）の波長点を加 えた計 22 の波長点の 合成分光反射率データを主成分分 析した。

パリマックス回転後の因子負荷量を基に各波長点にお ける合成分光反射率の相関度合いを額の色についてみて みると, 図9の如くとなる。なお，図 9 と酷似した眓が 顂, 唇の色の合成分光反射率データについても得られて いる。

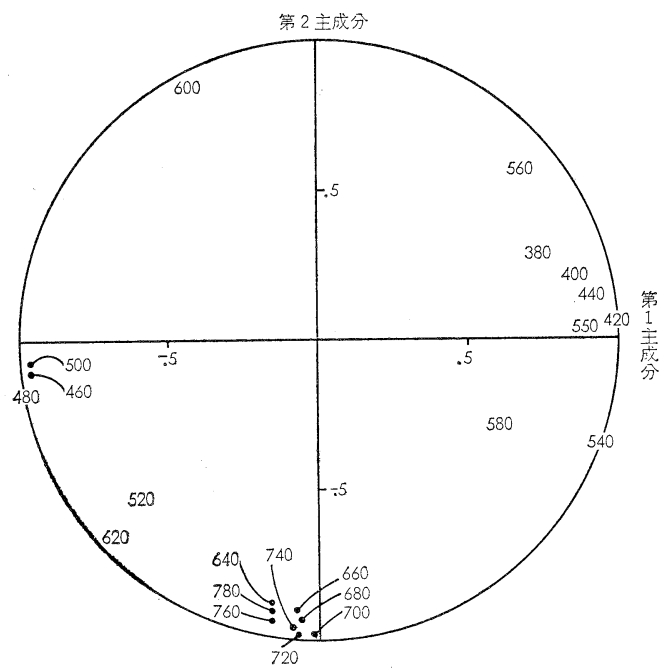

図 9 第 1 ，第 2 主成分との相関係数（因子負荷量） を基に位置づけた各波長位置

図9から次のことが言える。

(1) 図8 に示した A，C波長領域の分光反射率と $\mathrm{B}$ 波長領域の分光反射率間には負の相関があ る。

(2) A， B，C 波長領域の分光反射率と D 波長領 域の分光反射率間には相関がなく，互いに独 立である。

ところで，(1)に記した内容を模式化すると図 10 に示

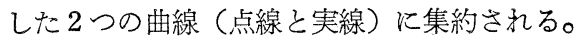




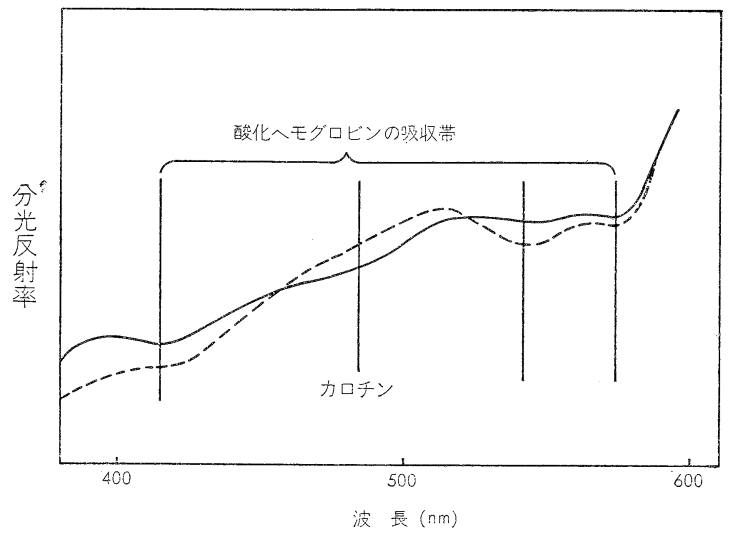

図10 条件等色している額の色の分光反射率曲線の典 型的な形を模式化した図

図10に示した分光反射率曲線が発生する原因は主と して, 皮膚表面から血管網京での距離の個人差と皮膚色 素の両者に由来する皮膚の光学特性（光の透過度や散乱 度）の変化，並びに酸化へモグロビンによる吸収に起因 すると推察される。

一方(2)の現象の発生原因は, (1)の現象の発生原因とは 別個のものが作用していると考光られるが，その発生機 軸は, いをのところ不明である。乙かし, 赤血球浮游液 の反射特性の湘定結果にみられる $760 \mathrm{~nm}$ 近辺の吸収や 赤血球濃度と区射率 $(660 \mathrm{~nm})$ の間に直線関係が成立し ないといら報告12) は興味深いものがある。更に水分に よる吸収 ${ }^{13)}$ とされる淰济同じ波長域の吸収も同様に興 昧深い。

このよらにみてくると, 皮膚色分布図上で明らかに異 なる点に位置する皮膚色の個人差の発生原因と条件等色 をおこさせる原因との間に，決定的に異なるものは見い 岋せない。今後更に解剖学的, 組織学的立場からの検討 が必要とされる。

\section{4. まとめ}

皮膚色（額・顆・唇）の分光反射率を測定すると共に 線形式のかたらで分光反射率を表示することを試みた。

更に皮膚色の分布領域内の任意の点の分光反射率を合 成でさるよらにした。

又，条件等色している皮膚色の分光反射率を合成し， その中味に吟味を加えた。

\section{5. 参考文献}

1) A. Izawa : Acta Chromatica 2, 147 (1972)

2) 丸井昌夫：口腔病学会誌 35, 3 (1968)

3）木兽山か叔，古元千鶴子，鈴木朋次郎，雲田直子 : 家政学雑誌 26, 57 (1975)

4) 木曾山加, 永井垣子: 家政学雑誌 26,149 (1975)

5) 木曾山か补, 小関文名, 鈴木朋次郎, 雲田直子： 家政学会誌：26,154 (1975)

6）森 於菟, 德橋 正, 松田直行, 渥美和郎, 米田 政彌，市川和子：東那医学会雑誌 3，5 (1956)

7）湯浅正治, 森田一二, 金子晶子：日本化粧品技術 者会会誌 10，34（1976）

8) E. A. Edwards et a1. : J. invest. Derm. 16, 311 (1951)

9) D. B. Judd et a1. : J. Opt. Soc. Am. 54, 1031 (1964)

10）納谷嘉信, 梠网 豊, 側垣博明 : 照明学会雑誌 55481 (1971)

11）金子 治, 花田千代美, 田中宗男：日本色彩学会 誌に投稿中

12）谷 彰：四国医誌 14，35 (1959)

13) J. A. Jacquey et al. : J. appl. Physiol. 8, 297 (1955)

（昭和53年 6 月 12 日受理） 